\title{
Electroless Ni-P Coatings: Preparation and Evaluation of Fracture Toughness and Scratch Hardness
}

\author{
Wagner Sade, ${ }^{1}$ Reinaldo Trindade Proença, ${ }^{2}$ Thiago Daniel de Oliveira Moura, ${ }^{1}$ \\ and José Roberto Tavares Branco ${ }^{1,2}$ \\ ${ }^{1}$ (Rede Temática em Engenharia de Materiais) REDEMAT, 35000-000 Ouro Preto, MG, Brazil
${ }^{2}$ Fundação Centro Tecnológica de Menas Gerais (CETEC), Avenida, José Cândido da Silveira, 2000 Bairro Horto, B.H,
31170-000 Belo Horizonte, MG, Brazil
}

Correspondence should be addressed to Reinaldo Trindade Proença, rtproenca@gmail.com

Received 11 May 2011; Accepted 21 June 2011

Academic Editors: C. S. Ha, W. Jiang, and D. Sarazin

Copyright (c) 2011 Wagner Sade et al. This is an open access article distributed under the Creative Commons Attribution License, which permits unrestricted use, distribution, and reproduction in any medium, provided the original work is properly cited.

\begin{abstract}
Ni-P chemical coatings have been used to prevent wear, corrosion and as an alternative for hard chromium, since the latter's deposition processing is very harmful to the human health and the environment. In the present paper, Ni-P coatings with 8 and $10 \% \mathrm{P}$ were deposited in steel AISI 1020 and thermally treated. Ni-1wt $\% \mathrm{P}$ coatings with incorporation of hard particles of $\mathrm{Al}_{2} \mathrm{O}_{3}$ were also investigated. The microstructure and phase relationships were analyzed and correlated with the fracture toughness and scratch hardness of the coatings. The results show that the fracture toughness of the coating was smaller when thermally treated at $400^{\circ} \mathrm{C}$ for 1 hour and the scratch hardness reached a peak in this temperature. The relation of chemical composition and microstructure with mechanical properties of Ni-P coatings is presented. The phosphorus contents, the crystallization, and the incorporation of hard particles in the coatings change the values of toughness fracture and scratch hardness.
\end{abstract}

\section{Introduction}

The use of coatings in surface engineering continues to increase in recent decades. Ni-P coatings, commercially available, combine high wear resistance and adhesion to the substrate. These kinds of coatings present a uniform thickness and can be used instead of hard chromium, decreasing health and environment problems. The wide use of these coatings stems from new prospects for improving the tribological properties of the coatings by thermal treatment and by the incorporation of hard particles such as alumina [1]. The process consists of electroless chemical reduction of $\mathrm{Ni}^{+2}$ to $\mathrm{Ni}^{0}$ and $\mathrm{P}^{+1}$ to $\mathrm{P}^{0}$ and simultaneous deposition on desired substrates. In the present study the effects of thermal treatment and the alumina hard particles incorporation were evaluated and related to fracture toughness and scratch hardness of Ni-P coatings.

\section{Methodology}

The coatings were deposited on steel AISI 1020. Before the coatings, the substrate was polished in $\mathrm{SiC}$ of 100 and
180 mesh. The substrates were cleaned through the use of absolute alcohol and etching with $\mathrm{HCl}, 30 \mathrm{wt} \%$, before the coatings to be applied [2]. The process was performed in a nickel sulphate and sodium hypophosphite solution at $90^{\circ} \mathrm{C}$ and the hydrogen ions concentration at the solution $(\mathrm{pH})$ was monitored according to the phosphorus content in the coatings. Figure 1 shows the influence of $\mathrm{pH}$ on the percentage of phosphorus in the coatings [3].

Branco et al. in 2006 [4] noted that for a $\mathrm{pH}=4$ the coatings present $10 \mathrm{wt} \% \mathrm{P}$ content, for a $\mathrm{pH}=5$ the phosphorus content is $8 \mathrm{wt} \%$, and for a $\mathrm{pH}=8$ the phosphorus content is $1 \mathrm{wt} \% \mathrm{P}$. As the $\mathrm{pH}$ of the bath has a tendency to lower to it becomes necessary drip an alkaline solution with ammonium hydroxide to $50 \%$ by volume. The higher the deposition time is, the increased the thickness of the coating. The Ni-8 wt\%P, $\mathrm{Ni}-10 \mathrm{wt} \% \mathrm{P}$, and $\mathrm{Ni}-1 \mathrm{wt} \% \mathrm{P} / \mathrm{Al}_{2} \mathrm{O}_{3}$ coatings were prepared in three chemical baths as shown in Table 1 .

After the coatings the samples of Ni-P were thermally treated in furnace at $300^{\circ} \mathrm{C}, 400^{\circ} \mathrm{C}$, and $600^{\circ} \mathrm{C}$ for 1 hour and cooled in the air.

The Ni-P/Al $\mathrm{A}_{2} \mathrm{O}_{3}$ coatings were performed by incorporation of alumina with $3 \mu \mathrm{m}$ size particles. The use of calgon 
TABLE 1: The chemical baths used in Ni-8\%P, Ni-10\% $\mathrm{P}$, and $\mathrm{Ni}-1 \% \mathrm{P} / \mathrm{Al}_{2} \mathrm{O}_{3}$ coating source [5].

\begin{tabular}{|c|c|c|c|c|}
\hline Constituents & Bath I (Ni-8\%P) & Bath II (Ni-10\%P) & Bath III $\left(\mathrm{Ni}-1 \% \mathrm{P} / \mathrm{Al}_{2} \mathrm{O}_{3}\right)$ & Role \\
\hline Nickel sulphate & $34 \mathrm{~g} / \mathrm{l}$ & $21 g / 1$ & $15 \mathrm{~g} / \mathrm{l}$ & Nickel source \\
\hline Sodium hypophosphite & $35 \mathrm{~g} / 1$ & $24 \mathrm{~g} / \mathrm{l}$ & $30 \mathrm{~g} / \mathrm{l}$ & Phosphorus source \\
\hline Malic acid & $35 \mathrm{~g} / 1$ & - & - & Accelerator \\
\hline Succinic acid & $12 \mathrm{~g} / \mathrm{l}$ & $5 \mathrm{~g} / 1$ & $10 \mathrm{~g} / \mathrm{l}$ & Accelerator \\
\hline Lactic acid & - & $28 \mathrm{~g} / 1$ & $50 \mathrm{~g} / \mathrm{l}$ & Complexing agent \\
\hline Thiourea & $1 \mathrm{ppm}$ & $2 \mathrm{ppm}$ & $3 \mathrm{ppm}$ & Stabilizer \\
\hline Ammonium hydroxide & $15 \mathrm{ml}$ & $15 \mathrm{ml}$ & $10 \mathrm{ml}$ & $\mathrm{pH}$ controller \\
\hline Alumina & - & - & $5 \mathrm{~g} / \mathrm{l}$ & Source \\
\hline Calgon & - & - & $5 \mathrm{~g} / 1$ & Surfactant \\
\hline $\mathrm{pH}$ & 5 & 4 & 8 & - \\
\hline Temperature & $90^{\circ} \mathrm{C}$ & $90^{\circ} \mathrm{C}$ & $90^{\circ} \mathrm{C}$ & - \\
\hline Deposition rate & $15 \mu \mathrm{m} / \mathrm{h}$ & $15 \mu \mathrm{m} / \mathrm{h}$ & $10 \mu \mathrm{m} / \mathrm{h}$ & - \\
\hline
\end{tabular}

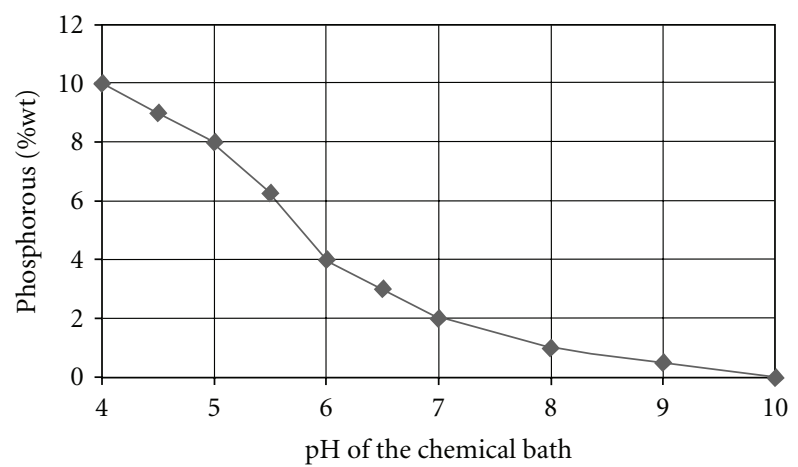

FIGURE 1: Variation curve of the phosphate content with the $\mathrm{pH}$ of the solution.

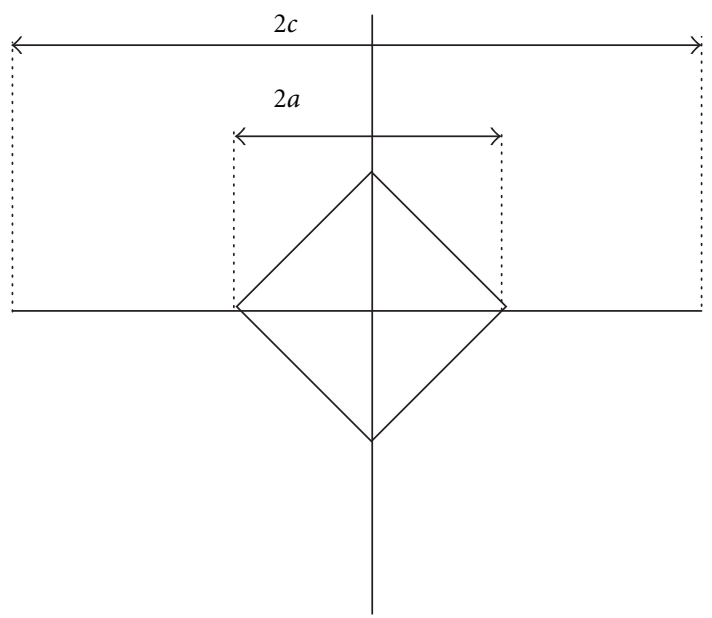

FIGURE 2: The schematic representative of crack by Vickers indentation.

surfactant is necessary in the chemical baths to stabilize the dispersion and improve the deposition of $\mathrm{Ni}-\mathrm{P} / \mathrm{Al}_{2} \mathrm{O}_{3}$ coatings.

The chemical composition of the coatings was analyzed by inductively coupled plasma optical emission spectroscopy
(ICP-OES). The thickness of the coating was determined by an optical microscope coupled with a graduated scale. The identification and the evaluation of the present phases in the coat were performed by X-ray diffraction (XRD). The microstructure of the sample and the present precipitates was examined by a scanning electron microscope (SEM). The coated samples were polished in $\mathrm{SiC}$ at 240, 400,600, 800, and 1500 mesh, and the last step was $1 \mu \mathrm{m}$ diamond. The chemical etching was carried out by 20 seconds in aqueous solution with $50 \%$ nitric acid and $30 \%$ acetic acid [6].

The fracture toughness $\left(K_{\mathrm{IC}}\right)$ for the Ni-P coated samples was measured by indentation test. A load " $P$ " of $100 \mathrm{~N}$ with a Vickers indenter was applied for 20 seconds in order to cause cracks in the samples. The value of semi-diagonals of impression (" $a$ ") and the length of cracks (" $2 c$ "), Figure 2, was measured by optical microscope.

The fracture toughness of coating, in $\mathrm{MP} \mathrm{a} \cdot \mathrm{m}^{1 / 2}$, was determined by Equation (1), proposed by [7]

$$
K_{\mathrm{IC}}=0,0319 \times \frac{P}{a \sqrt{c}},
$$

where

$K_{\mathrm{IC}}$ is the value of fracture toughness $\left(\mathrm{MPa} \cdot \mathrm{m}^{1 / 2}\right)$;

$P$ is the value of applied load indentation $(\mathrm{N})$;

$a$ is the semidiagonals of indentation (m);

$2 c$ is the length of cracks in the direction of diagonal (m).

The scratch test was used to evaluate the hardness of the coatings. The tests were performed with a Rockwell $\mathrm{C}$ indenter, with a diamond cone and opening angle of $120^{\circ}$ at rate of $100 \mathrm{~N} / \mathrm{min}$ and speed of $10 \mathrm{~mm} / \mathrm{min}$. The scratches measured roughly $7 \mathrm{~mm}$ and were analyzed by optical microscope.

The scratch hardness of coatings was determined using (2) [8]:

$$
H_{s}=8 \frac{F_{N}}{\pi b^{2}}
$$

where 


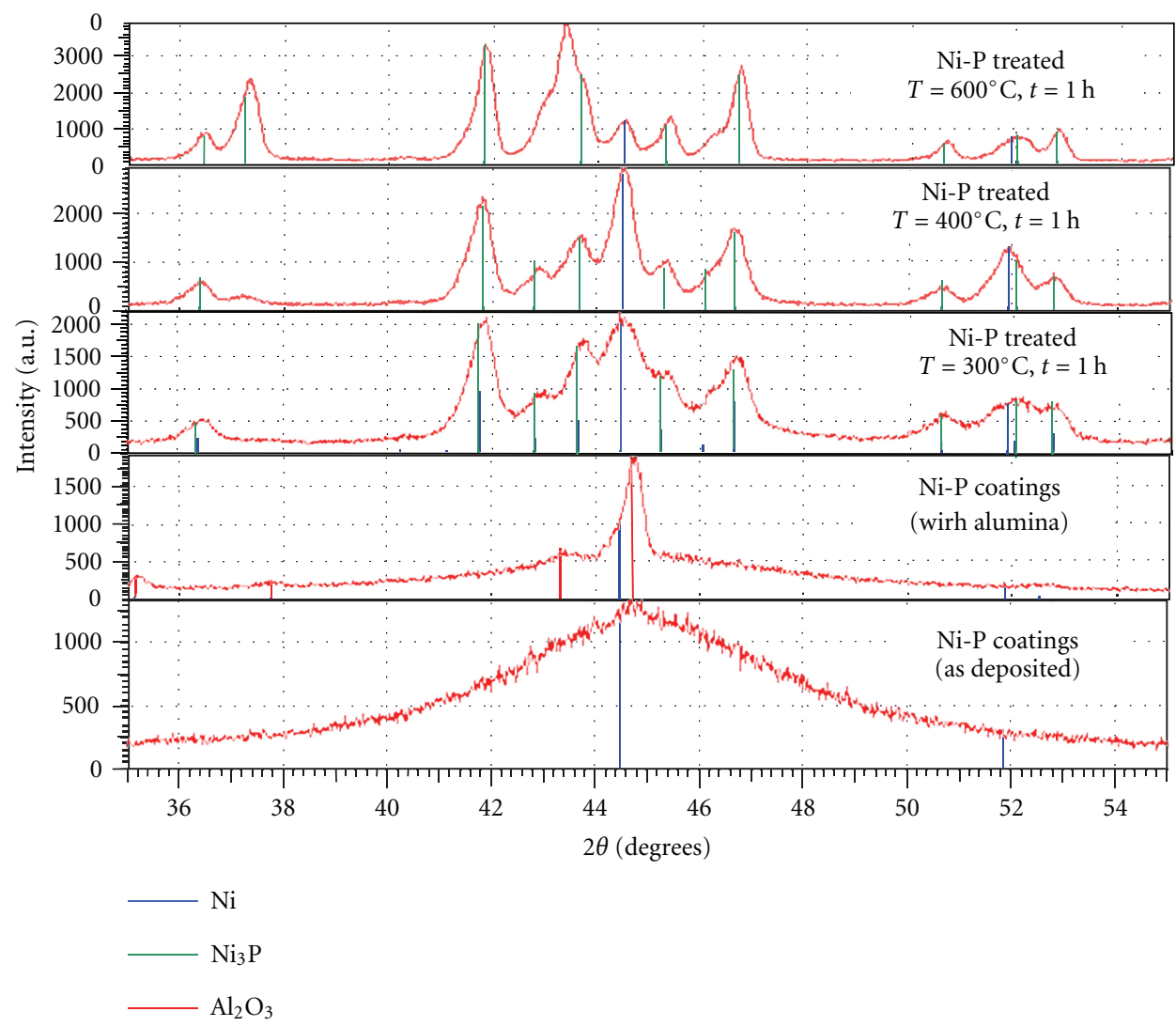

(a)

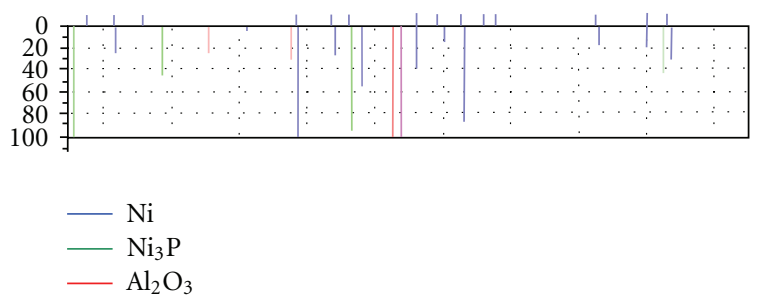

(b)

FIGURE 3: XRD patterns of Ni-8\%P coatings as deposited, thermally treated, and with alumina.

$H_{s}$ is the scratch hardness of the material (MPa);

$F_{N}$ is the normal force in scratch test $(\mathrm{N})$;

$b$ is the width of scratch $(\mathrm{mm})$ relative to this normal force.

\section{Results and Discussion}

3.1. The Thickness and Chemical Composition of Ni-P and $\mathrm{Ni}-\mathrm{P} / \mathrm{Al}_{2} \mathrm{O}_{3}$ Coatings. The thickness of the coating measured roughly $10 \mu \mathrm{m}$. Table 2 shows the chemical analyses of Ni-P and $\mathrm{Ni}-\mathrm{P} / \mathrm{Al}_{2} \mathrm{O}_{3}$ coatings. The phosphorus content in $\mathrm{Ni}-8 \%$ $\mathrm{P}$ and $\mathrm{Ni}-10 \% \mathrm{P}$ coatings is the same, as estimated by the chemical baths with their $\mathrm{pH}=5$ and $\mathrm{pH}=4$, respectively. Note that $\mathrm{Al}_{2} \mathrm{O}_{3}$ content in the coatings is roughly $31 \%$.
TABle 2: Nickel, phosphorus and $\mathrm{Al}_{2} \mathrm{O}_{3}$ contents in coatings by weight.

\begin{tabular}{lccc}
\hline Coatings & $\mathrm{Ni}(\%)$ & $\mathrm{P}(\%)$ & $\mathrm{Al}_{2} \mathrm{O}_{3}(\%)$ \\
\hline $\mathrm{Ni}-8 \% \mathrm{P}$ & $92.3 \pm 0.5$ & $7.7 \pm 0.5$ & - \\
$\mathrm{Ni}-10 \% \mathrm{P}$ & $89.7 \pm 0.2$ & $10.3 \pm 0.2$ & - \\
$\mathrm{Ni}-1 \% \mathrm{P} / \mathrm{Al}_{2} \mathrm{O}_{3}$ & $62.0 \pm 0.4$ & $7.3 \pm 0.4$ & $30.7 \pm 0.4$ \\
\hline
\end{tabular}

3.2. Analyses of X-Ray Diffraction. The diffractograms of $\mathrm{Ni}-8 \% \mathrm{P}$ coatings, thermally treated, and $\mathrm{Ni}-1 \% \mathrm{P} / \mathrm{Al}_{2} \mathrm{O}_{3}$ are shown in Figure 3. The profile of Ni-8\% $\mathrm{P}$ coatings, as deposited, is characteristic of amorphous materials. There is a peak at $2 \theta=44.5^{\circ}$ for $\mathrm{Ni}-\beta$ phase, which has a face-centered cubic (FCC) structure. The $\alpha$-alumina phase, present in $\mathrm{Ni}$ $1 \% \mathrm{P} / \mathrm{Al}_{2} \mathrm{O}_{3}$ coatings, has a rhombohedral structure at $2 \theta$ 


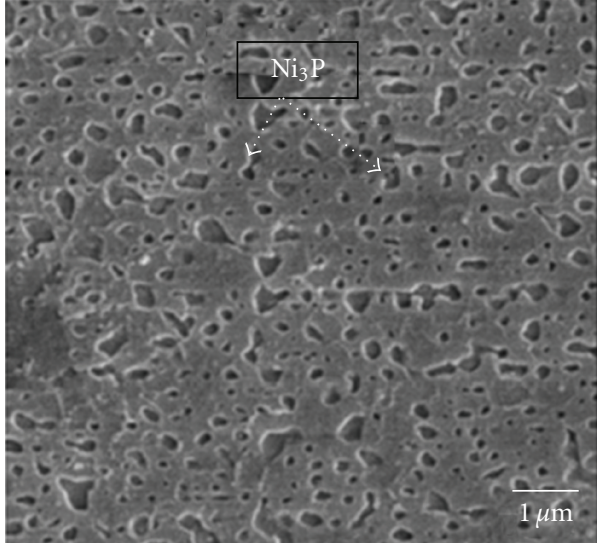

(a)

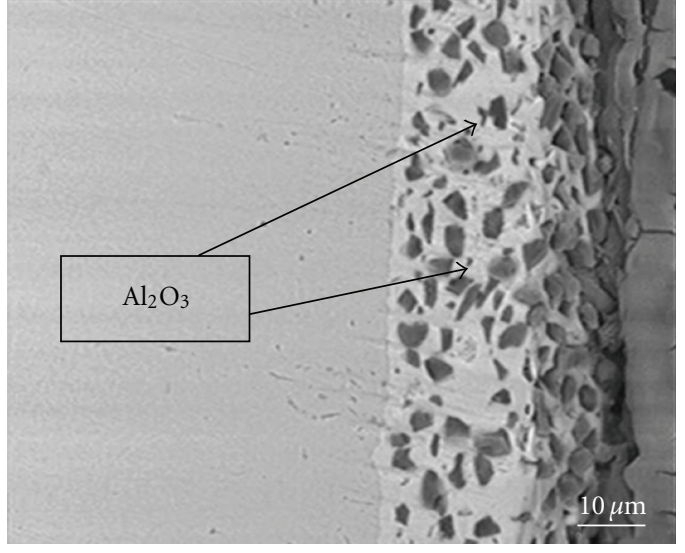

(b)

FIGURE 4: Samples of Ni-10\%P coatings as deposited (a) and with incorporation of $\mathrm{Al}_{2} \mathrm{O}_{3}$ hard particles (b). Images by SEM.

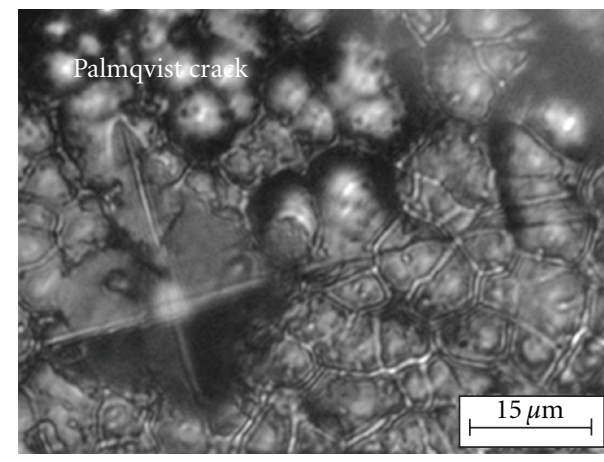

FIgure 5: The crack Palmqvist in $\mathrm{Ni}-1 \% \mathrm{P} / \mathrm{A}_{2} \mathrm{O}_{3}$.

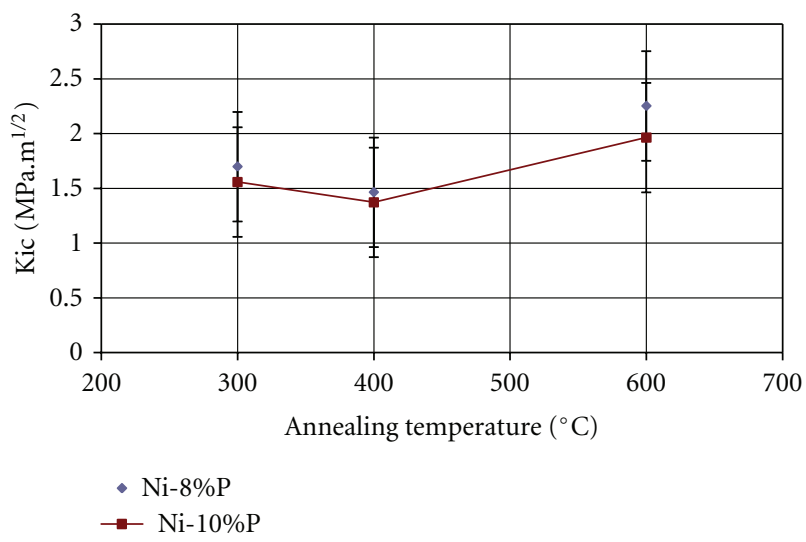

Figure 6: Values of fracture toughness of Ni-P coatings thermally treated for 1 hour.

$=35.1^{\circ}, 37.1^{\circ}$, and $45.3^{\circ}$. Li et al. in 2004 [9] also found similar results in their studies. The phase that corresponds to the nickel phosphides appears when the coatings of $\mathrm{Ni}$ $\mathrm{P}$ are treated at $300^{\circ} \mathrm{C}$ for 1 hour. At this temperature, the amorphous Ni crystallizes to FCC. The structure of the nickel phosphide is tetragonal [10]. The intensity of the peaks of
$\mathrm{Ni}-\mathrm{P}$ coatings increases with annealing temperature because of the crystallization of phosphides. At high temperatures, $400^{\circ} \mathrm{C}$ and $600^{\circ} \mathrm{C}$ the peaks of $\mathrm{Ni}, \mathrm{Ni}_{3} \mathrm{P}$ and $\mathrm{Al}_{2} \mathrm{O}_{3}$ have high intensity. Gao et al. in 2005 [11] also found similar results in their works.

3.3. Microstructure. The microstructures of the coatings are shown in Figure 3 . The $\beta$ phase consists of a solid solution of nickel and phosphorus that can hold up to $4.5 \%$, by weight, of phosphorus. The $\gamma$ phase is metastable where the phosphides precipitates appear between 11 and 15\%P [2]. The nickel phosphides are a hard phase. Figure 4(a) shows a sample of Ni-10\% P coating as, deposited and Figure 4(b) shows the Ni-P coatings with incorporation of $\mathrm{Al}_{2} \mathrm{O}_{3}$. This phase is harder than the nickel phosphides [12].

When the phosphorus content increases, from 8 to $10 \%$, this increases the nickel phosphides content and the propagation of Palmqvist type cracks (Figure 5). The increase of phosphides precipitates embedded in nickel matrix decreases the fracture toughness of the coatings. The propagation of cracks has a higher probability of finding a hard phase of nickel phosphides. The toughness fracture of coatings with $8 \% \mathrm{P}$ is greater than coatings with $10 \% \mathrm{P}$ in same conditions. For the coatings with alumina hard particles, such as the case of $\mathrm{Ni}-1 \% \mathrm{P} / \mathrm{Al}_{2} \mathrm{O}_{3}$ coatings, this probability increases.

3.4. Toughness Fracture of Coatings. The fracture occurs when the hard phase is subjected to stress fields [13]. The influence of temperature on the fracture toughness of the Ni$\mathrm{P}$ coatings can be evaluated in the graphs shown in Figure 6. There were no cracks in Ni-P and Ni-P/A $\mathrm{O}_{3}$ coatings as deposited.

Note that there is a decrease in fracture toughness when the coatings were treated until $400^{\circ} \mathrm{C}$ for 1 hour. The fracture toughness of Ni-P coatings has a lower value, $1.4 \mathrm{MPa} \cdot \mathrm{m}^{1 / 2}$ $(\mathrm{Ni}-10 \% \mathrm{P})$, at $400^{\circ} \mathrm{C}$. The highest toughness values occur at $600^{\circ} \mathrm{C}$, about $2.3 \mathrm{MPa} \cdot \mathrm{m}^{1 / 2}(\mathrm{Ni}-8 \% \mathrm{P})$ and $1.9 \mathrm{MPa} \cdot \mathrm{m}^{1 / 2}$ $(\mathrm{Ni}-10 \% \mathrm{P})$. The values of fracture toughness are high for these amorphous coatings, that is, as deposited. Bozzini et al. 


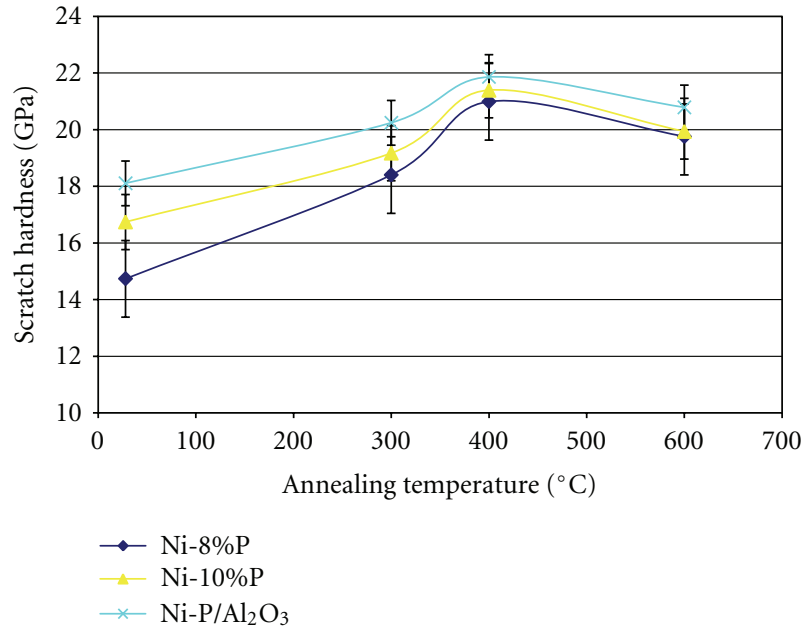

FIGURE 7: Values of scratch hardness for the coatings evaluated.

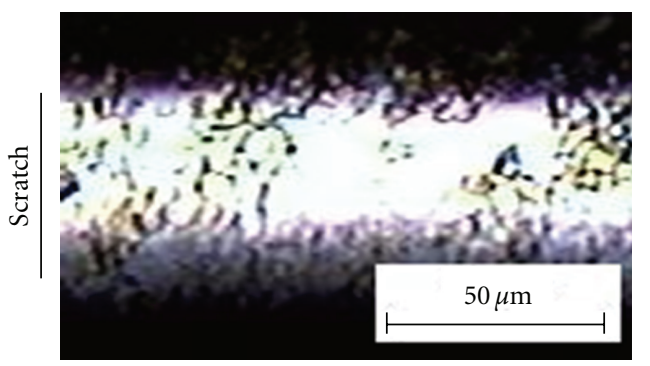

FIGURE 8: Image of the scratch in the Ni-8\%P coating thermally treated at $600^{\circ} \mathrm{C}$.

2001 [14] obtained a value of $7.5 \mathrm{MPa} \cdot \mathrm{m}^{1 / 2}$ for the fracture toughness in $\mathrm{Ni}-9 \% \mathrm{P}$ coatings. Increasing the fracture toughness is related to the coalescing of particles $\mathrm{Ni}_{3} \mathrm{P}$, where the ductile matrix $\mathrm{Ni}$ isolates the hard particles of $\mathrm{Ni}_{3} \mathrm{P}$, preventing the spread of breakage particle to particle.

3.5. Results of Scratch Hardness. The scratch hardness was determined by (2) where $b$ is the width of the scratch. The values are shown in the graph in Figure 7. On the Mohs scale, used by mineralogists, diamonds have a hardness of 10 which corresponds to $61 \mathrm{GPa}[8]$. The scratch hardness of $\mathrm{Ni}-\mathrm{P} / \mathrm{A}_{2} \mathrm{O}_{3}$ coatings as deposited, $18 \mathrm{GPa}$, is greater than the hardness of $\mathrm{Ni}-8 \% \mathrm{P}$ and $\mathrm{Ni}-10 \% \mathrm{P}$ in same conditions, $15 \mathrm{GPa}$ and $17 \mathrm{GPa}$, respectively.

At temperatures below $400^{\circ} \mathrm{C}$, the hardness increases due to phase transformation of amorphous Ni-P to cermets $\mathrm{Ni}_{3} \mathrm{P}$ embedded in matrix of crystalline $\mathrm{Ni}$ [15]. For the temperature at $400^{\circ} \mathrm{C}$, the scratch hardness of coatings reaches greater values. The larger value is roughly $21 \mathrm{GPa}$ for $\mathrm{Ni}-10 \% \mathrm{P}$ coating. At temperatures above $400^{\circ} \mathrm{C}$, the size of the particles of phosphides grows and reduces the hardness.

Figure 8 presents an image of the scratch after delaminating of the substrate, obtained in the scratch test for $\mathrm{Ni}-8 \% \mathrm{P}$ coatings treated at $600^{\circ} \mathrm{C}$ for 1 hour.

\section{Conclusions}

The evolution phase of coatings thermally treated was observed from the results of X-ray diffraction that show the presence of $\mathrm{Ni}-\beta$ phase and nickel phosphides that crystallize from the amorphous phase. These peaks of crystallization increase with annealing temperature.

$\mathrm{Ni}-1 \% \mathrm{P} / \mathrm{Al}_{2} \mathrm{O}_{3}$ composite coatings plated from stable dispersions in EN baths exhibit excellent particle distribution even at particle incorporation levels approaching $30 \%$ by weight. A large increase in particle concentration in the growing layer during plating was observed for surfactants systems plated from baths with particle concentration of $5 \mathrm{~g} / \mathrm{L}$.

The fracture toughness and scratch hardness vary depending upon the annealing treatment. This fact is due mainly to the crystallization and precipitation of the phases present and the coalescing of phosphides. The values of fracture toughness decrease until the thermal treatment of $400^{\circ} \mathrm{C}$ and increase after this temperature. The values of fracture toughness by Vickers indentation of Ni-P and $\mathrm{Ni}-1 \% \mathrm{P} / \mathrm{Al}_{2} \mathrm{O}_{3}$ coatings, as deposited, were not found. These values are very large because there was no crack by indentation. The value of scratch hardness of Ni-P coatings increases until the thermal treatment temperature of $400^{\circ} \mathrm{C}$ and decreases after this temperature. The incorporation of $\mathrm{Al}_{2} \mathrm{O}_{3}$ particles on the Ni-P coatings, as deposited, increases the scratch hardness of these coatings. This process is the hardening by incorporation of hard particles. The Ni-P/ $\mathrm{Al}_{2} \mathrm{O}_{3}$ coatings, as deposited, are harder than the $\mathrm{Ni}-8 \% \mathrm{P}$ and $\mathrm{Ni}-10 \% \mathrm{P}$ coatings.

The results of the present study reveal a relation of chemical composition, microstructure with mechanical properties of Ni-P coatings. Thus, the phosphorus contents, the crystallization, and the incorporation of hard particles in the coatings change the values of toughness fracture and scratch hardness.

\section{Acknowledgment}

The authors acknowledge the financial support from the Conselho Nacional de Desenvolvimento Científico e Tecnológico $(\mathrm{CNPq})$ and Fundação Centro Tecnológico de Minas Gerais (CETEC).

\section{References}

[1] K. Krishnaveni, T. S. N. Sankara Narayanan, and S. K. Seshadri, "Electroless Ni-B coatings: preparation and evaluation of hardness and wear resistance," Surface and Coatings Technology, vol. 190, no. 1, pp. 115-121, 2005.

[2] I. Apachitei, F. D. Tichelaar, J. Duszczyk, and L. Katgerman, "The effect of heat treatment on the structure and abrasive wear resistance of autocatalytic NiP and NiP-SiC coatings," Surface and Coatings Technology, vol. 149, no. 2-3, pp. 263278, 2002.

[3] E. G. Neiva, Microabrasion Analysis of Chemical coatings Ni$P$ and the Effect of Incorporation of $\mathrm{Al}_{2} \mathrm{O}_{3}$, M.S. Dissertation, REDEMAT, Brazil, 2007. 
[4] J. R. T. Branco, E. Neiva, G. Sade, W. Moura, and C. W. Silva, "Evaluation of Mechanical and Tribologycal Properties of Ni$\mathrm{P}$ and $\mathrm{Ni}-\mathrm{P} / \mathrm{Al}_{2} \mathrm{O}_{3}$ Coating," Conference Materials, University of Coimbra, Portugal, 2007.

[5] ASM Handbook Commitee, "Electroless Nickel-Plating, Surface Engineering," American Society for Metals, vol. 5, p. 291, 1994.

[6] M. Sarret, C. Müller, and A. Amell, "Electroless NiP microand nano-composite coatings," Surface and Coatings Technology, vol. 201, no. 1-2, pp. 389-395, 2006.

[7] J. Lesage, A. Roman, and D. Chicot, "Indentation tests to determine the fracture toughness of nickel phosphorus coatings," Surface and Coatings Technology, vol. 155, no. 2-3, pp. 161-168, 2002.

[8] ASM Handbook Commitee, "Microindentation Hardness Testing, Oak Ridge National Laboratory," Metals Handbook, vol. 18 , pp. 414-433, 18.

[9] G. J. Li, R. M. Ren, X. X. Huang, and J. K. Guo, "Microstructure and mechanical properties of $\mathrm{Al}_{2} \mathrm{O}_{3} / \mathrm{Ni}$ composites," Ceramics International, vol. 30, no. 6, pp. 977-982, 2004.

[10] S. Alirezaei, S. M. Monirvaghefi, M. Salehi, and A. Saatchi, "Wear behavior of Ni-P and Ni-P- $\mathrm{Al}_{2} \mathrm{O}_{3}$ electroless coatings," Wear, vol. 262, no. 7-8, pp. 978-985, 2007.

[11] J. Gao, Y. Wu, L. Liu, and W. Hu, "Crystallization behavior of nanometer-sized $\mathrm{Al}_{2} \mathrm{O}_{3}$ composite coatings prepared by electroless deposition," Materials Letters, vol. 59, no. 2-3, pp. 391-394, 2005.

[12] Y. de Hazan, D. Werner, M. Z'graggen, M. Groteklaes, and T. Graule, "Homogeneous Ni-P/Al $\mathrm{O}_{3}$ nanocomposite coatings from stable dispersions in electroless nickel baths," Journal of Colloid and Interface Science, vol. 328, no. 1, pp. 103-109, 2008.

[13] L. Jacomine, Effect of production parameters of Ni-P coatings in the abrasive wear, Dissertation, University of Uberlândia, Brasil, 2004.

[14] B. Bozzini, M. Boniardi, A. Fanigliulo, and F. Bogani, "Tribological properties of electroless Ni-P/diamond composite films," Materials Research Bulletin, vol. 36, no. 11, pp. 18891902, 2001.

[15] S. H. Park and D. N. Lee, "A study on the microstructure and phase transformation of electroless nickel deposits," Journal of Materials Science, vol. 23, no. 5, pp. 1643-1654, 1988. 

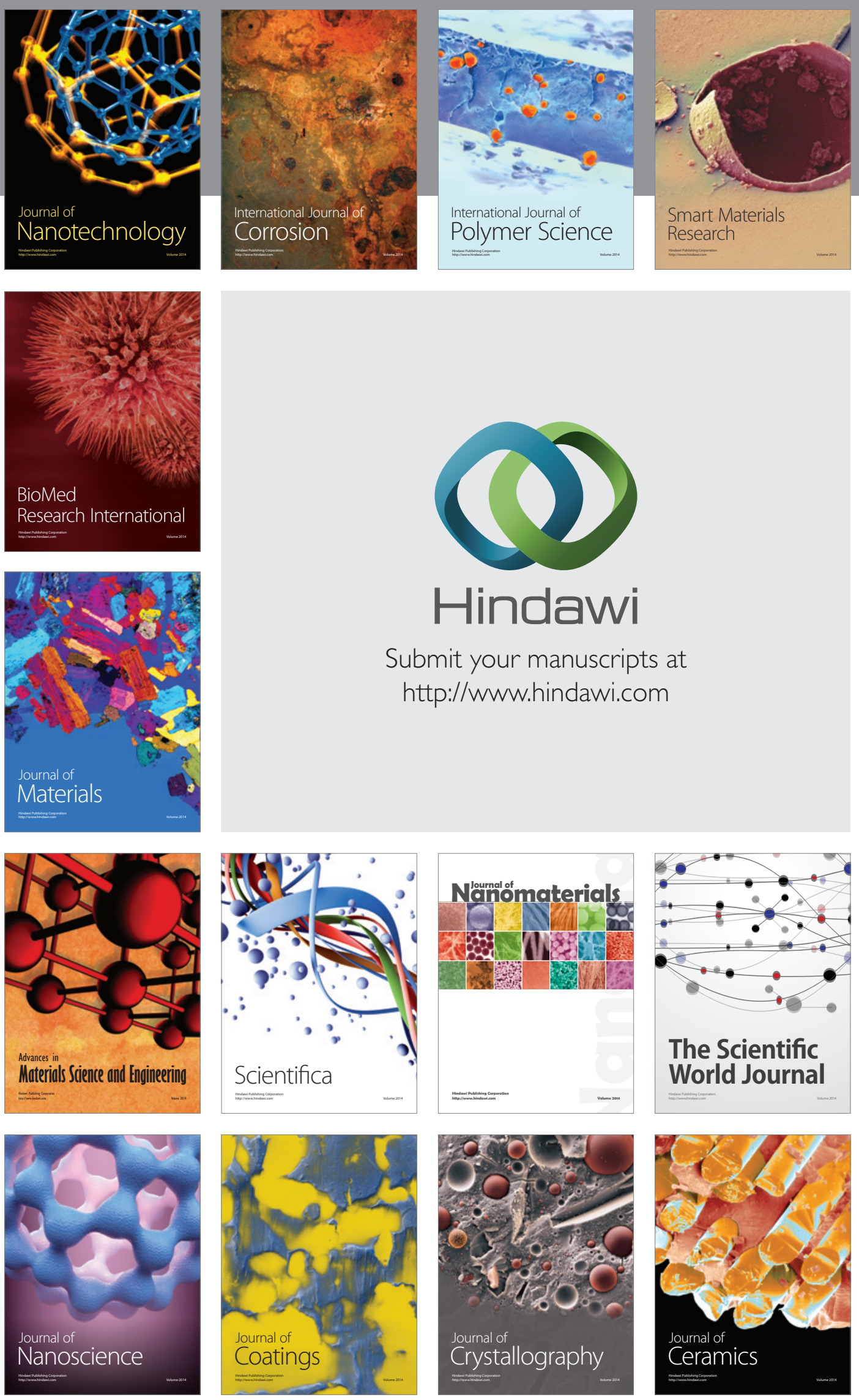

The Scientific World Journal

Submit your manuscripts at

http://www.hindawi.com

\section{World Journal}

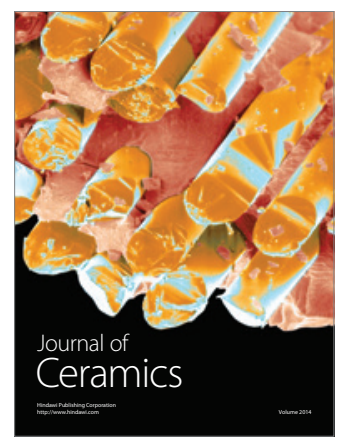

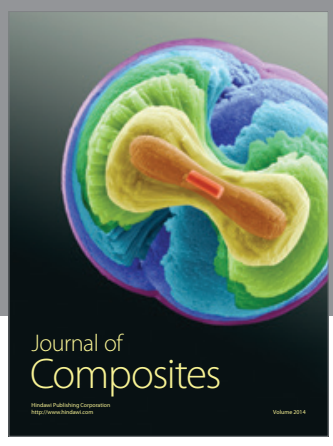
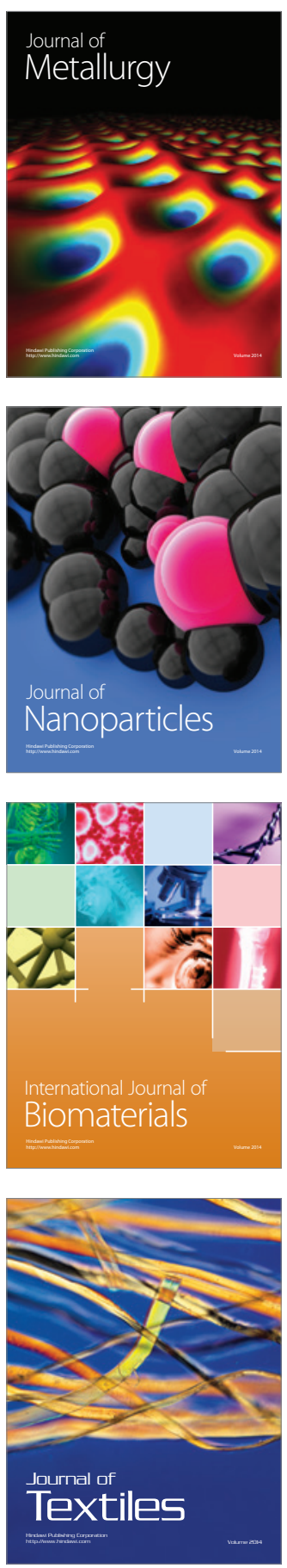